<時論 >

\title{
米国発、新コレステロールガイドライン（2013 年）の衝撃
}

\author{
奥山治美 1 、浜崎智仁 2 、大櫛陽一 3 \\ ${ }^{1}$ 名古屋市立大学、金城学院大学消費生活科学研究所、 ${ }^{2}$ 富山大学、富山城南温泉第 \\ 二病院、 ${ }^{3}$ 東海大学、大櫛医学情報研究所 \\ 連絡先 : 奥山治美、金城学院大学消費生活科学研究所、 $\bar{T} 463-8521$ 名古屋市守 \\ 山区大森2-1723、TEL\&Fax 052-876-3840 ; E-mai1:okuyamah@kinjo-u. ac. jp \\ キーワード : ACC/AHAガイドライン2013、日本動脈硬化学会ガイドライン2012、日 \\ 本脂質栄養学会ガイドライン2010、10年-冠疾患死亡確率
}

\section{The impact of a new cholesterol guideline issued from the USA}

\author{
Harumi Okuyama ${ }^{1}$, Tomohito Hamazaki ${ }^{2}$, Yoichi Ogushi ${ }^{3}$ \\ ${ }^{1}$ Nagoya City University and Kinjo Gakuin University, ${ }^{2}$ Toyama University and Toyama \\ Jonan Onsen Daini Hospital, ${ }^{3}$ Tokai University
}

\section{Summary}

Previous cholesterol guidelines for the prevention of CHD were based on "the lower, the better" hypothesis, setting upper LDL-C limits and treating patients to maintain their cholesterol levels below the targets, as seen in the ATP III issued from the National Heart, Lung, and Blood Institute (NHLBI) and that issued from the Japan Atherosclerosis Society (JAS GL). We published a new cholesterol guideline for longevity (JSLN GL 2010), in which evidence was presented that a high cholesterol level is not a causative factor of CHD but is a predictor of longevity among general populations over 40-50 years of age. Recently, a long-waited revision of the ATP III was published from the NHLBI in conjunction with the American College of Cardiology and the American Heart Association (ACC/AHA GL 2013), in which "setting targets to treating patients with statins" and "the lower, the better hypothesis" were abandoned because of the lack of clinical evidence. However, both the JAS GL 2012 and ACC/AHA GL 2013 brought about estimated 10year CHD (ASCVD) risk mainly based on NIPPON DATA 80 and NHLBI-supported studies, respectively, 
resulting in increased estimated number of subjects to be treated with statins. Here, we point out that the estimated 10-year risks are not usable because they are not evidence-based. Moreover, we summarize biochemical mechanisms underlying the statin actions to increase heart failure, diabetes mellitus and other diseases after long-term treatments. The cases for which statins, all mitochondrion-toxic, are applicable should be extremely restricted.

Key words: ACC/AHA guideline 2013, JAS guidelines 2012, JSLN Guidelines for longevity 2010, estimated 10 year-ASCVD risk.

\section{Iはじめに-本稿で比較するコレステロール ガイドライン}

コレステロール值が高いと動脈硬化が進む、といらコレステロール仮説は 1950 年代から始まり、 1990 年代には悪玉 LDL-C/善玉 HDL-C 仮説となり最近まで続いてきた。米国がこの流れを主導して おり、米国心肺血液研究所(National Heart, Lung, and Blood Institute, NHLBI)が 2001 年に だしたAdult Treatment Panel (ATPIIIと略)を、わが国を始め多くの国がそれぞれの国に合わせ たガイドラインを作る基礎とした。この ATPIIIの改訂版が 2004 年に出されて以来、これに合わない多 くの臨床論文が発表され、次の改訂版がいつ出るかと騒がれていた。ここ2, 3 年は米国の冠疾患関 係の学会が開かれるたびに、「今年も出なかった」といらニュースが聞かれた。新ガイドラインは NHLBI との共同で米国心臓病学会(American College of Cardiology, ACC) と米国心臓協会 (American Heart Association, AHA)から 2013 年 11 月 12 日に公表された(ACC/AHA GL 2013 と 略) ${ }^{1)}$ 。

一方、わが国では日本動脈硬化学会が中心となり動脈硬化性疾患予防ガイドライン 2007 年版が出 され、2012 年に改定版が出された(動硬 GL 2012 と略) 2)。これらは本質的にATPIII と同じ万向であっ た。そしてわが国では現在、動硬 GL 2012 についての広報活動が各都市で頻繁に行われている。 ATPIIIも動硬 GL 2012 ももに、「コレステロール值は低ければ低いほどよいりという理解に基づき、病 態に応じてコレステロールの管理目標值を決め、それを維持するためにコレステロール低下剤(スタ チン)を使用する、といら医療を中心にすえている。

略号:ACC, 米国心臓病学会 (American College of Cardiology); AHA, 米国心臓势会, American Heart Association); ASCVD、動脈硬化性心疾患 (atherosclerotic cardiovascular disease); CHD, 冠動脈心疾患、冠 疾患； FH，家族性高コレステロール血症；LDL-C, 低比重年ポンパクコレステロール；NHLBI, 米国心肺 血液研究所(National Heart, Lung, and Blood Institute)；TC，総コレステロール 
われわれは日本脂質栄養学会を中心として「長寿のためのコレステロールガイドライン 2010 年版をを 公表したが (長寿 GL 2010 と略) ${ }^{3)}$ 、これはATPIII 2004 および動硬GL 2007 と根本的に異なる新しい 方向を示したもので、その内容は次のように要約できる。

\section{長寿 GL 2010 の要点}

(1) コレステロール值の冠疾患に対する相対危険度は、調査集団により、また年齢により 1 以下 (負の相関)から 5 以上(正の相関)と大きく変わる。家族性高コレステロール血症 $(\mathrm{FH})$ は LDL 受 容体機能に障害があり、若齢時よりコレステロール值が高く、冠疾患死亡率も高く、平均生存率 が低いが、集団中の FH の割合が相対危険度の変動をもたらす主因子であると理解できる。すな わち、FH と非FHは区別すべきである。

(2) 企業が中心となって行われた臨床試験の多くについて非倫理的な問題が露見し、企業中心の 臨床試験報告は信頼できない、といら議論が超一流の医学誌上で公然と議論されるようになつ た。これを背景に臨床試験についての罰則付きの新規制が EUで作られ 2004 年に発胶た。そ れ以前の 1990 年代に「スタチンは LDL-C 值を下げ、冠疾患イベントを 3 割前後下げる」といら多 くの臨床論文が発表されたが、2004 年以降、企業と利益相反のないチームにより行われた臨床 試験はすべて、「スタチンは LDL-C 值を下げるが有意な冠疾患予防効果は認められなかった」、 と報告した。動硬GL 2012 は 1990 年代に行われた企業中心の論文を含むメ夕解析の結果に基 づき、LDL-C 值の低下が冠疾患予防に有効であるとしているが、長寿 GL 2010 は後者に基づ き、LDL-C 值が高いことは冠疾患の原因となっていないと結論した。

(3) 冠疾患とコレステロール值の間に有意な正相関がない集団が多くあり、それが一般者の大部分 である。さらに、コレステロール值が高い群ほじ癌や脳卒中、全死因による死亡率が低く、高コレ ステロール值は長寿の指標となっている。れれら集団ではコレステロール低下医療は不適切 である。

(4) コレステロールエステル輸送タンパク(CETP)の阻害剤が開発され、臨床的にスタチンとの併用 で LDL-C 值の低下、HDL-C 值の上昇が認められた。しかし、冠疾患予防効果は認められず、総 死亡率が有意に上がったため臨床試験を中止した(ILLUMINATE 研究)。すなおち、コレステロー ルの善玉、悪玉説は崩壊した。

(5) 脳卒中死亡率とコレステロール值は負の相関を示し、コレステロールや飽和脂肪酸の摂取が多 い群ほど脳卒中死亡率が低い。また脳卒中で緊急入院した患者のうち、高脂血症と診断されて いる人の方が予後がよい ${ }^{4)}$ 。脳卒中予防にスタチンは使うべきではない。 
6) 中性脂肪(TAG) 高值が冠疾患の危険因子であることを示寸エビデンスは認められていない。

(7) 冠疾患予防のためには、高リノール酸 $(\omega 6)$ 植物油および動物で脳卒中促進作用を示す植物油 脂の摂取を減らし、 $\omega 3$ 系油脂の摂取を増やす、あるいは EPA 製剤、DHA 製剤を使うことを勧め る。

\section{ACC/AHA GL 2013 の概略および動硬 GL2012、長寿 GL2010 との相違点}

動硬 GL 2012 ではATPIIIに沿つた形で、コレステロールの管理目標值を設定し、それ以下に保つ ことを下記のように勧めている(Fig. 1)。

\section{動硬 GL 2012 のコレステロール管理目標値}

(1) 冠疾患既往者では LDL-C 值として $100 \mathrm{mg} / \mathrm{dL}$ 未満、

(2) 糖尿病、慢性腎臓病、非心原性脳梗塞、あるいは未梢動脈疾患の人では $120 \mathrm{mg} / \mathrm{dL}$ 未満、

(3)このようなリスクは持たないが、NIPPON DATA 80 を基礎とした 10 年-冠疾患死亡確率(絶対少 ク)が $0.5 \sim 2.0 \%$ のでは、 $140 \mathrm{mg} / \mathrm{dL}$ 未満、

(4) 10 年一冠疾患师クが $0.5 \%$ 未満の場合は $160 \mathrm{mg} / \mathrm{dL}$ 未満。

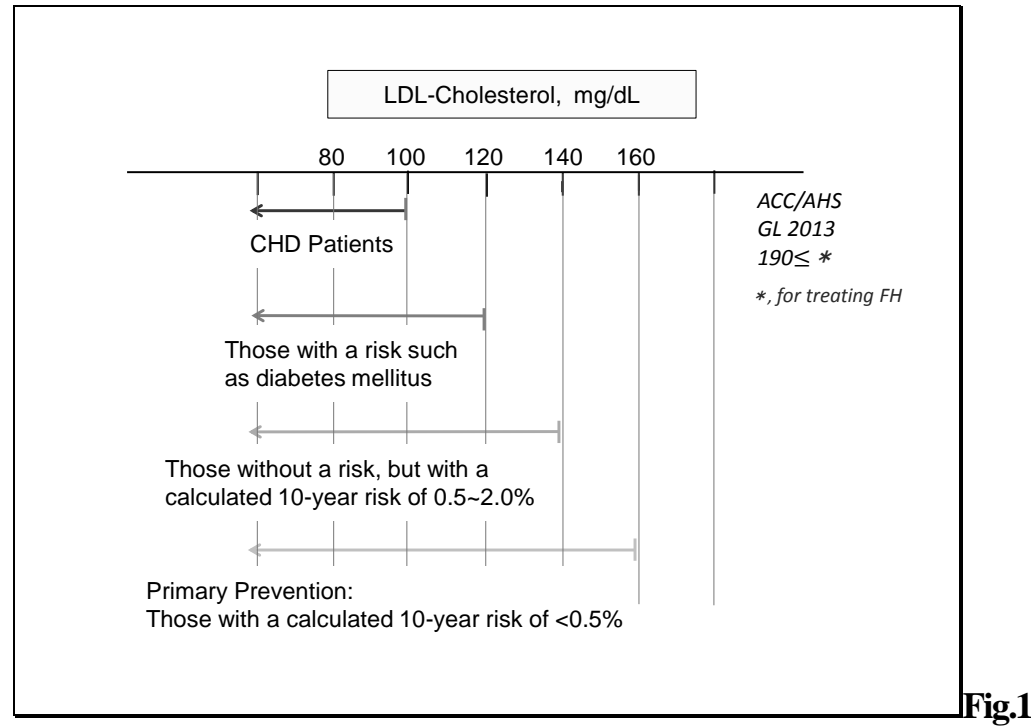

Fig.1. The targets defined in the JAS Guidelines for the Prevention of Atherosclerotic Cardiovascular Diseases 2012 (動 硬 GL 2012 のコレステロール管理目標值)：For those with or without diseases indicated, the upper limits of LDL-C were defined to maintain their levels below these targets. In contrast, the ACC/AHA guideline 2013 noted LDL-C levels of $\geqq 190 \mathrm{mg} / \mathrm{dL}$ for the treatment of familial hypercholesterolemia cases with statin, but abandoned to set the LDL-C limits such as those shown in this figure. 
今回公表された米国 ACC/AHA GL 2013 が臨床家に与えた衝撃の最大のものは、「LDL-C あるいは non-HDL-Cの管理目標值を設定し、それ以下に保つためにスタチンを使う」という医療を、臨床的工 ビデンスがないとして放棄したことである。さらに、「低ければ低いほどよい説も、エビデンスがない として葬ったことである。

このことは、上記、動硬GL 2012 の(1)と(2)を否定したわけで、日本動脈硬化学会および関連医 学会は、完全に“はしごを外されたかにみえる。修正版を出すかあるいは独自の路線を突き進むの か、速やかな対応が求められている。

われわれの長寿GL 2010 が提起した上記(1)〜 7)については、ACC/AHA GL 2013 の内容にかかわ らず修正すべき点はない。

さて ACC/AHA GL 2013 は「コレステロールの管理目標值を設け、それ未満に保つといら医療はエビ デンスがないとして放棄したが、スタチンの使用を放棄したわけではなかった。スタチン以外のコレ ステロール低下剤の有効性は認めなかったものの、次の 4 群についてスタチンは有効であるとして いる。

(1)ASCVD (atherosclerotic cardiovascular disease)既往の人

(2) LDL-C 值が $190 \mathrm{mg} / \mathrm{dL}$ 以上の人

(3) $40 \sim 75$ 歳の糖尿病者で、 LDL-C 值が 70-189mg/dL の人

(4) $40 \sim 75$ 歳の人で冠疾患、糖尿病をもたず、 LDL-C 值が 70-189mg/dL であるが、 10 年-ASCVD リスク が $7.5 \%$ 以上の人

76 歳以上の高齢者を対象としていないこと、LDL-C のカットオフを $190 \mathrm{mg} / \mathrm{dl}$ としたことなどは長寿 GL2010 と矛盾せず評価できる。しかしの4群でスタチンが有効であるとするエビデンスは、いずれ も不十分であることを次に指摘する。

\section{長寿 GL 2010 側からの指摘}

（1）動硬GL 2012 もACC/AHA 2013 も冠疾患既往者にはスタチン療法を無条件で認めており、これ は無作為割付対照試験(RCT) でエビデンスがあるとしているが、2004 年 EU 新規制以降の臨床試験 では、冠疾患に対する有効性が認められていない。さらに、スタチンはミトコンドリア毒であり心筋の ATP 産生を阻害すること、微量元素 Se の久乏症と共通のメカニズムにより心不全を発症させることな どが生化学的に明らかにされてきた。横紋筋融解症に相当する作用が心筋(横紋筋)にも働き、長期 的には心疾患が増えることが予測できる。 
（2）スタチンはFH に対しても有効性は認められておらず、FH では冠疾患死亡者と生存者の間にコ レステロール值の差がない。FHにおいても高 LDL-C 值そのものは冠疾患の原因とはなっておらず、 末梢細胞へのエネルギー源(TAG) やコレステロールの持続的な供給不足(長寿 GL2010)、血栓性の 亢進などがこの場合の冠疾患の原因として指摘されている5)。

（3）糖尿病の主要合併症として冠疾患があることから、糖尿病一コレステロール—冠疾患の因果関 係を考察することなく、糖尿病者にスタチン治療を無条件で認めている(動硬 GL 2012、ACC/AHA 2013)。しかしわれわれは、糖尿病者にスタチンは禁忌とする緊急提言を発信した ${ }^{6)}$ 。その根拠は、

（ア）スタチンが糖尿病を新規発症させることが臨床的に明確となった(先進国では添付文書に注意 書きが載っている)、(イ)スタチンが糖尿病を発症させる生化学的劝ズムが明らかになってきた、 の二点である。コレステロールレベルの低下に伴うラフト構造の変化によるインスリン受容体への影 響、プレニル中間体から作られる CoQ やへム A を介したミトコンドリア機能低下とケトン体合成阻害、 プレニル中間体から作られるイソペンテニルアデニン合成の阻害による過酸化ストレスの上昇やイン スリン受容体のプロセシングの障害およびインスリン抵抗性の上昇、プレニル中間体から作られるドリ コールの低下によるインスリン受容体のプロセシング障害など、スタチン投与期間が長くなるほど糖 尿病発症がす寸むことを示している ${ }^{6)}$ 。LDL-C 值を下げても糖㽷病者の冠疾患予防ができないことか ら、スタチンは糖尿病者にはとくに禁忌となる。

次にACC/AHA GL 2013 および動硬 GL 2012 にそっと忍び込まされている 10 年-(冠疾患死亡確 率あるいは ASCVD 発症確率)リスクを検証してみよう。米国では 10 年-ASCVD リスクを採用することに なれば、スタチン治療の対象者が 3,000 万人(現在の 2 倍)に増えると推測されている。多くのスタ チンの特許が切れ、OTC(over the counter)薬になって処方箋なしに薬局で買えるようになると、企 業にはこれまで以上の利益が約束されることになる。この薬の不可逆な有害作用(催奇性、発癌作 用、中枢障害など)が短期間では明らかになりにくく、加齢にともなってあらわれる症状と区別儿にく いことから、OTC 薬への認可が進むとしたら一大事となるであろう。

\section{ACC/AHA GL2013 における 10 年-ASCVDリスクの計算ツールの問題}

10 年冠疾患死亡確率はフラミンガム市民 30～74 歳の追跡研究に基づき、性、年齢、TC、LDL-C、 など各種因子に配点し、ポイントを合計して、表に基づきリスクスコアを求めるものであった(Wilson PWF ら、1998)。現在では否定されている LDL-C と HDL-C に正と負のポイントを与えるとか、加齢ととも にコレステロールの相対危険度が小さくなるといら報告と合わず、利用できるものではなかったが、計 
算の原理は単純明快であった。その後、フラミンガム市民 50 歳の追跡に基づく冠動脈疾患生涯ス クが少し複雑な計算により示されているが(Lloyed-Jones DM ら、2006)、(ア)評価項目が心筋梗塞 と脳卒中に加えて、心不全、狭心症、跛行も含まれている。これらの疾患に対してスタチンの有効性 は認められていないので、冠動脈疾患生涯スクとスタチンの必要性とは関係が無い、(イ)フラミンガ ム市民の 50 歳時点のベースラインデータのみに基づいているので、他の年齢層への適応はできな い(ウ)研究対象者が男性 3564 人、女性 4362 人と少なく信頼性が低い、などの問題があった。 最新の ASCVD (冠疾患、脳卒中など) 10 年-発症確率(10 年- ASCVD リスクと略) は、NHLBI の支援L た研究(フラミンガム研究と他の三研究)の対象者 $(25,000$ 人)の追跡調査の結果に基づく式で計算 される(Fig. 2$)^{7)}$ 。

ACC/AHA GL2013が提案する10年-ASCVD死亡確率 0 計算法 Got DC el a. J Am Coll Cardid (2014), dd:10.10 15:10x.2013.11.005

\section{Estimated 10-year risk $=1-S_{10}^{a}$$$
a=e^{b-c}
$$

$\mathrm{S}_{10}$ : survival rate at 10 year

b: Individual sum of 12.344 Ln Age + 11.853 Ln TC -2.664 Ln Agex LnTC - 7990 Ln HDL-C + 1.769 Ln Age $\times$ Ln HDL-C) + $1.797 \mathrm{Ln}$ (treated systolic BP) + 1.764Ln(untre ated systolic BP) + 7.837 C urrent $s$ moker $(1=y e s, 0=$ no) -1.795 LnAgexCurrentsmoker + 0.658 D iabetes ( $1=y e s, 0=$ no)

where the figures are the given coefficients for white men and the $\mathrm{Ln}$ repres ents natural logarithm.

C: race and sexspecific overall mean (coefficient $x$ value) sum

\section{Fig.2}

Fig.2 The equation to calculate 10-year ASCVD risks adopted in the ACC/AHA Guideline 2013.

See text for details. Clinicians seem to be requested simply to enter clinical data to a programmed calculator to obtain a 10year risk value. Different coefficient values are given for female and for African Americans.

評価スクは1から 10 年生存率(S10)のa乗を差し引ルたものである。はは自然刘数の低 $(e)$ の $(b-$

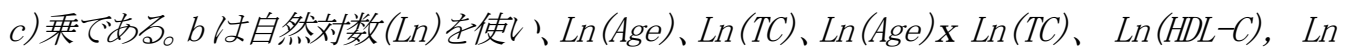
(Age) $x$ Ln $(H D L-C) 、 L n($ systolic BP) , Ln (Age) x Ln(treated systolic BP)、 Ln (untreated systolic BP)、Ln(Age $)_{x}$ Ln (untreated systolic BP)、 Current smoker 
(1=Yes，0=No)、Ln (Age) x Current smoker、Diabetes (1=Yes，0=No)のそれぞれに、与えら れた正あるいは負の係数を乗じたものの紛和しして求められる。cは集団の平圴值について計算し た值である。これは白人男性用であり、女性には少し異なる式を使う。アフリカ系米国人には異なる 倸数が与えられている。

この原報 ${ }^{7)}$ にいて、次のような問題がある。(ア)対数変換した因子やその積を使った医学統計 学的説明が必要である、(イ)TC 值が式で使われているのに、ガイドライン本文では LDL-C で基準を 決めているのでツールとしては不適切である、(ウ)使われている係数の合理性(再現性、信頼性)に 大きな問題がある。たとえば白人女性では年齢が予防因子となっている、女性の方が男性より TCリス クが高くなっている、黒人女性の血圧的ク係数が他の集団より一桁大きくなつているが、白人と黒人 の遺伝子は 99. 99\% 一致しており係数の大きな差を合理的に説明できない、(エ)この式は発症率を 予測するだけでありスタチン療法の効果を予測しているわけではない、などである。

フラミンガム市民についての他の研究では、(ア)加齢に伴い TC 值の冠疾患に対する相対危険度 が小さくなる、(イ 14 年の観察期間に TC 值の低下した群では、続く 18 年の冠疾患死亡率、総死亡 率が有意に高かったと報告されているが ${ }^{8)}$ この式に合うとは考えられない。また、多くの遺伝子学者 は人種による薬物効果の差を否定している。

重要なことは、このように求められる 10 年-ASCVD リスク スコアが、臨床的に当てはまることを示す 研究はどこにもない、ということである。

\section{IV 動硬 GL 2012 における 10 年-(冠疾患死亡確率)リスクとNIPPON DATA 80 に基づくチャートの 問題点}

動硬 GL 2012 ではすでに、 LDL-C や HDL-C とともに 10 年-冠疾患死亡確率少スクを使っている(上 述)。これは厚生労働省循環器疾患基礎調査の結果(NIPPON DATA80) ${ }^{9)}$ に基づきスコア化し、チャー トで示したものである。男女性別、血糖值で 2 群、コレステロール值で 6 群、血圧で 5 群、年齢で 4 群、喫煙状態で 2 群に分けたので 480 枠があり、各々に対する 10 年-冠疾患死亡確率(絶対少スク) が求められたものである。各枠は確率 $0.5 \%$ 未満から $10 \%$ 以上に 6 種に色分けされている。上述、動 硬 GL 2012 のコレステロール管理目標值、(3)」では 10 年-リスクとして 0.5-2. 0\%が使われている。 この NIPPON DATA 80 は対象者が少なすぎ、それに基づく10 年-絶対少スク評価チャ一トは臨床の場 で使えるものではないことは、浜崎らにより別に解析、報告されている ${ }^{10)}$ 。例えば 480 枠に対応する 
冠疾患死亡数は 67 例以下であり、随時血糖值 $\geqq 200 \mathrm{mg} / \mathrm{dL}$ の 240 枠に対する総対象者数は 67 名、 冠疾患死亡数は 5 例以下である(男性の場合)。さらに次のような諸問題がある。

(1) NIPPON DATA 80 の対象者は若龄者に偏つており(長寿 GL 2010 で指摘)、一般集団に適用でき ない、

(2) 一般に加齢とともにコレステロール值の冠疾患死に対する相対危険度が小さくなるが (長寿 GL2010)、それがチャートに反映されていない、

(3) 冠疾患死亡率とコレステロール值が負の相関、あるいはその傾向を示寸臨床試験結果、例えば 守口市民研究 ${ }^{11)}$ と合わない、

(4) コレステロール值と冠疾患死亡率の関係は不連続的であり、コレステロール最高值群のみ冠疾 患の相対危険度が上がるといらわが国の大規模追跡調査結果、JACC 研究 ${ }^{12)}$ 、茨城健康調査 ${ }^{13)}$ と合 わない、

(5)この計算された確率(リスク)の妥当性を示寸臨床研究は全くない、 などである。

以上のような観点から、10 年一冠疾患死亡確率にもとづくチャートは、わが国の医療の現場に適用 すべきものではない、と結論する。このようなデータを駆使して意図的にスタチン治療の対象者を増 やしているとすれば、それはほとんど犯罪的であるとさえいえる。

\section{V おわりに一 迷路への導入を許すな！}

コレステロールと動脈硬化の因果関係が TC 值で説明できなくなり、LDL-C/HDL-C 説へと進んだ。こ れが破たんするとその先には 10 年-冠疾患死亡確率が準備されていた。この10 年-リスクといら指標 は多くの矛盾する報告を無視することによってつくられており、科学的であるとはいえない。何よりも 臨床的に全く検証されていないものである。このように先々に気を巡らせて多忙な臨床医を混乱の 場、迷路へと導こうとするのは、その裏に巨額の利益が絡んでいるからであろう。このような利益相反 の構困は多くの国で暴力れてきた。

スタチンは単に心臓脳血管疾患の予防に効果がない,ということだけでは済まされない。数年の臨 床試験では顕わにならなかった不可逆な有害作用が、長期的にはすべからくあらわれることは、これ までに明らかにされてきた生化学的な作用双ニズムから容易に予測できる ${ }^{6)}$ 。OTC 薬として成人の 3 割以上がサプリメント並みに使うようなことになれば、グローバルな薬害問題が発生するであろう。 
40 歳以上の全員のコレステロール值を測定し、その管理目標值を定め、それを維持するためのコ レステロール低下療法を行う制度は、先進国中で日本が最も発達しているように見える。この制度 が、いわゆる権威があり日本の医療界が依存してきた機関(ACC/AHA、NHLBI)で、「臨床的エビデンス なし」と断罪されたのである。これを機に、ミトコンドリア毒としてのスタチンの作用を見極め、多くの医 療面でコレステロール低下医療の道を引き返す勇気が求められている。

\section{参考文献}

1. Stone NJ, Robinson J, Lichtenstein AH et al. Circulation published on line November 12, 2013;

http://circ. ahajournals. org/content/early/2013/11/11/01. cir. 0000437738. 63853. 7a. c itation

2. 日本動脈硬化学会 動脈硬化性疾患予防ガイドライン 2012 年版、(社) 日本動脈硬化学会、 2012 年

3. 日本脂質栄養学会、長寿のためのコレステロールガイドライン、中日出版社、2010 年

4. Ogushi Y, Hamazaki T, Kirihara Y. World Rev Nutr Diet. 100:63-70, 2009

5. Sugrue DD, Trayner I, Thompson GR et al. Br Heart J. 53: 265-8, 1985

6. 奥山治美、浜崎智仁、大櫛陽一ら、脂質栄養学 22；173-86，2013

7. Goff DC, Lloyd-Jones DM, Bennett G et al. J Am Coll Cardiol (2014), doi:10. 1016/j. jacc. 2013.11.005)

8. Anderson KM, Castelli WP et al. JAMA. 257:2176-80, 1987

9. NIPPON DATA 80 Research Group, Circ J. 70:1249-1255, 2006

10. 浜崎智仁、奥山治美、浜六郎ら、脂質栄養学 23: in press， 2014

11. Tsuji H. Arch Intern Med. 2011; 171(12):1121-3

12. Cui R, Iso H, Toyoshima H et al. Atherosclerosis. 194: 415-20, 2007.

13. Noda H, Iso H, Irie F et al. Circulation. 119: 2136-45, 2009. 